\title{
The Impact of Tourism Service Quality on Customer Satisfaction and Behavioural Intention
}

\author{
Ghada Abdalla \\ Tourism Studies Department \\ Faculty of Tourism and Hotels \\ Suez Canal University
}

\author{
Abd Elazim Basiony \\ Sinai High Institute of Tourism \\ and Hotels, Ras Sider
}

\author{
Alaa Mohamed shaker El Sayed \\ Tourism Studies Department \\ Faculty of Tourism and Hotels \\ Suez Canal University
}

\begin{abstract}
Service quality (SERVQUAL) has received a considerable attention in the last 50 years. While Service quality is well documented in literature, fewer studies have been investigating the relationship of service quality with customer satisfaction and behavioural intention, and particularly in tourism. The aim of this paper is to examine the causal direct and indirect impact of service quality on customer satisfaction and behavioural intention. A total of 390 usable responses were obtained with a response rate of $71 \%$. Structural equation modelling was used to analysis the current research data. The structural equation modelling results indicate that all the employed dimensions to measure service quality (tangibility, reliability, responsiveness, assurance, and empathy) have a direct influence on customer satisfaction and indirect impact on behavioural intention through customer satisfaction. These results help to clarify the mixed findings in the literature concerning the pattern of the causal relationship between service quality with customer satisfaction and behavioural intention. Finally, conclusions and limitations are outlined.
\end{abstract}

Key words: Service quality, customer satisfaction, behavioural intention, SERVPERF

\section{Introduction}

Tourism in Egypt has long been a driving train of growth and one of the largest sources of foreign currencies. Its share represents $19.3 \%$ of total income of foreign currencies. The tourism sector is considered as one of the main creators of employment, accounting for $12.6 \%$ of the employed population $(24,000,000)$. Tourism as a labour intensive industry generates jobs in almost 70 related sectors (Alexbank, 2010). Thus, Eraqi (2006) claimed that, for success in a highly competitive tourism market, a tourism destination has to make sure it is providing the goods or services that the customer needs; gets its quality right; and delivers on time. This can lead to customer (tourist) satisfaction and achieving a suitable level of profits (Kandampully, 2001). Since the 1990's, many studies examine the relationship between service quality and customer satisfaction, and service quality and behavioural intention in various industries (Parasuraman et al., 1988; Carman 1990; Cronin and Taylor, 1992; Asubonteng et al., 1996; Lee and Cunningham 2001; Jones et al., 2002; Santos, 2003). Despite the important theoretical role of service quality in improving customer satisfaction and behavioural intention, few empirical studies have investigated this relationship. However, there is a contradiction in the literature concerning (1) the dimensional structure of service quality and (2) which service quality dimensions can affect customer satisfaction and behavioural intention. The aim of the current study is to evaluate the service quality offered to British tourist regarding their satisfaction and behavioural intention. This study is applied on the British tourist as according to the UNWTO (2014), the world's five major spenders on tourism was china (US\$ 128.6 billion) followed by USA (US\$ 86.2 billion) followed by Germany (US\$ 85.9 billion), Russian Federation (US\$ 53.5 billion), UK (US\$ 52.6 billion) and France (US\$ 37 billion). Moreover, the large number of Egyptian visitors comes from Russia (2,855 tourist, 19\%), UK (1,456 tourists $10 \%)$, Germany $(1,329$ tourists $8 \%$ ) and Italy (1,144 tourists 8\%) (Ministry of Tourism, 2010). In this regard, and by taking into consideration the high expenditure rate of the UK visitors and the large number that comes to Egypt, the current study aims to evaluate the tourism service quality provided to UK tourists regarding their satisfaction and behavioural intention.

\section{Service quality}

Nowadays, quality is gaining an importance in all areas of life. In tourism industry, guests require "products" where they are assured of getting high-quality, value-for-money services. The additional reasons for organized quality in tourism are widely documented: growing competition, lack of willingness to provide a service, growing loss of individuality by standardization of products. (UNWTO, 2004). Service Quality has been defined differently by different authors. Parasuraman et al. (1985) defined service quality as "the degree and direction of discrepancy between customers" perceptions and expectations", and "Perceived service quality" as "the gap between customers' expectations and 
perceptions, as a measurement of service quality". So, the smaller the gap, the better the service quality provided, and the greatest the customer satisfaction.

In recent years, measuring service quality has received increasing attention in the tourism literature (Hudsonet al., 2004). Literature including service quality in the hospitality industry can be categorized into three major groups: human resource related, strategy and management related, and service quality measurement issues. Some examples of the service quality articles related to the measurement of service quality using the SERVQUAL or the modified instrument to identify the perception of service quality in the hospitality industry (Douglas and Connor, 2003; Juwaheer and Ross, 2003; Antony, Antony and Ghosh, 2004; Ndhlovu and Senguder, 2002; Chen et al., 2001; Tsang and Qu, 2000). Another group concerns the constructs of service quality measurement combined with those using other techniques. This group includes Getty and Getty (2003); Olorunniwo et al. (2003); Hersh (2010); Akbaba (2006); Haghkhah et al. (2011); Yu et al. ( 2005) and Clemenz. (2001).

\section{Service Quality Dimensions}

Regardless of the type of service, consumers used basically similar criteria in evaluating service quality. These criteria seem to fall into $10 \mathrm{key}$ categories which are labelled service quality determinants (dimensions) that company executives consistently mentioned in terms of consumers' evaluations of service quality. Parasuraman et al., (1985) defined the ten determinants of service quality as follows (Reliability, Responsiveness, Competence, Access, Courtesy, Communication, Credibility, Security, Understanding and Tangibles). Further research made by Parasuraman et al. (1988) conclude that consumers use five underlying dimensions in judging service quality, so these ten were later reduced to five through exploratory factor analysis by Parasuraman, et al. (1988). The five final dimensions factored down to:

1- Tangibles: Physical facilities, equipment, the appearance of personnel and communication materials.

2- Reliability: Ability to perform the promised service dependably and accurately.

3- Responsiveness: Willingness to help customers and provide prompt service.

4- Assurance: Knowledge and courtesy of employees and their ability to convey trust and confidence.

5- Empathy: Caring, individualized attention the firm provides its customers

These five dimensions appear again along with the scale developed to measure them which is called "SERVQUAl". These dimensions represent how consumers organize information about service quality in their mind (Zeithaml et al., 2006).

\section{The measurement of service quality}

The conceptualization and measurement of service quality perceptions have been the most debated topics in the services marketing literature to date. In addition, there are many failed attempts either to mix the SERVQUAL/SERVPERF conceptualization into new industries (e.g., Durvasula et al., 1999; Kettinger et al., 1995) or to repeat its conceptual structure (e.g., Asubonteng et al., 1996; Kettinger and Lee 1995; Mels et al., 1997; Van Dyke et al., 1997). Indeed, perceived service quality has proved to be a difficult concept. A call for research that specifically examines the "dimensionality" of the service quality construct (Parasuraman, Zei-thaml, and Berry, 1994) has yet to be successfully addressed. Given the importance of customers' perceptions of quality in a service context, it is no surprise that numerous studies have been devoted to its measurement (Ladhari, 2008). Examples of service quality models include the Nordic model (Grönroos, 1984; 2007); SERVPERF (Cronin and Taylor, 1992); and SERVQUAL (Parasuraman et al., 1988). SERVQUAL is the most commonly used model applied and examined across a variety of tourism and leisure contexts and is hence described in more detail (Radder and Han, 2011). It might be accepted today that service quality is a multidimensional construct (this assumption will be tested in the current study through exploratory factor analysis). There have been a variety of service quality models (measures) in the literature. One of the widely used models is the SERVQUAL/SEVPERF (Kouthouris and Alexandris, 2005)

\section{SERVQUAL model}

SERVQUAL model based on the original conceptual gap model of service quality produced by Parasuraman et al. (1985, 1988 and 1991). The SERVQUAL model consists of 22 items on service attributes developed by Parasuraman et al., (1988) which are grouped along the five dimensions of tangibles, reliability, assurance, responsiveness, and empathy to measure customers' expectations (E) and perceptions (P) of the five RATER dimensions. Four or five numbered items are used to measure each dimension. The SERVQUAL was a questionnaire that examined customers' perceived service quality by measuring customer expectation in the first portion, and their perceived service performance in the second portion (Narangajavana, 2007). 
Although its growing popularity and widespread application, SERVQUAL has been subjected to a number of criticisms (Buttle, 1996). Despite the fact that the SERVQUAL model might be an excellent instrument for measuring service quality, several researchers comment on the SERVQUAL model, indicating that there are some shortcomings and defects associated with SERVQUAL, The SERVQUAL was criticized for its predictive power, and length. Hoffman and Bateson (2006) argued about the length of the SERVQUAL questionnaire because it consists of 44 questions to measure customer expectations and perceptions. This may result in respondent fatigue. Cronin (1992: 1994) and Brady et al., (2002) preferred the use of the only perception of service performance to measure service quality (Narangajavana, 2007; Zhang, 2009). Hoffman and Bateson (1997) mentioned the critique about the predictive power of the SERVQUAL (measuring both expectation and perception): its ability to predict customer purchase intention was less than the modified instrument that measured only the perception of service performance. Service quality required to have customer satisfaction as a mediating variable that affected purchase intention. Cronin and Taylor (1992) stated that "service quality is an antecedent of consumer satisfaction and that consumer satisfaction exerts a stronger influence on purchase intention than does service quality". They suggested for the managerial purpose the customer satisfaction program should be more emphasized than strategies that focused exclusively on service quality (Narangajavana, 2007).

Regards the measurement of expectations, Baron and Harris (2003) argued that the timing of expectation measurements is of crucial importance. In SERVQUAL, respondents must rate their expectations and perceptions of a particular service on the same scale for each of the 22 items. Moreover, respondents are often interviewed only once and questioned to rate both their expectations and perceptions on one occasion. If respondents are using these retrospective expectations in their post-purchase evaluations, the initially measured expectations are disputable by the biased experience of the respondents (Zhang, 2009). These above-mentioned criticisms led Cronin and Taylor $(1992 ; 1994)$ to conclude that it is much better to use questions about performance (=perception) and delete all the questions on expectations. That is the essence of their SERVPERF model. In fact, the SERVPERF model is based on the perception items in SER VQUAL. One of the arguments is that the predictive validity of using only the perceptions component is higher than in using the difference (perception-expectation) scores (Parasuraman et al., 1994 and Zhang, 2009). It has also been argued that the performanceonly measure proposed by Cronin and Taylor (1994) (the SERVPERF) explains more variance in an overall measure of service quality than SERVQUAL instrument (Tahir Jan, 2012).

\section{The SERVPERF Measurement (Performance-based measure)}

Since the 90s, many researchers have been studying the service quality in relation to factors affect customer satisfaction, loyalty, and behavioural intention in different industries. Prior studies had further developed recommendations to increase service performance (Parasuraman et al., 1988; Carman 1990; Cronin and Taylor, 1992; Asubonteng et al., 1996; Lee and Cunningham 2001; Jones et al., 2002; Santos, 2003). Other studies have been also done in airline industry (Chin, 2002), hotels industry (Pei et al., 2006), and banking services (Haron, et al., 1994; Levesqueand McDougall, 1996; Babakus et.al., 2004). The empirical research of Cronin and Taylor (1992) suggested that measuring service quality from only the perceptions of the service experience. For more consistent results of the analysis of a structural model, they recommended using "SERVPERF" -a modified SERVQUAL instrument to measure service quality. The five dimensions of SERVQUAL scale (Parasuraman et.al., 1988) include the physical facilities, equipment and the appearance of the staff (Tangibles); the dependability and accuracy of the service provider (Reliability); the ability to know and willingness to cater to customer needs (Responsiveness); the ability of staff to instil confidence and trust in the company (Assurance); and finally, the ability of the staff in providing a caring service to customers (Empathy). Instead of measuring both customer expectations and perceptions as in the SERVQUAL, the SERVPERF was operationalized by only one part of the perceived performance. It did not assess the gap scores between expectation and perception as the expectation does not exist in the SERVPERF. Therefore, by excluding the measurement of customer expectation, a total of only 22 items remained in the new measure. Cronin and Taylor (1992) concluded that the SERVPERF was a superior service quality measurement in comparison to the SERVQUAL. In addition, the results demonstrated that the new measure had more predictive power on the overall service quality judgment than the original instrument (Narangajavana, 2007).

Moreover, while it seems logical that identifying the gaps is the best way to define quality, identify possible problems and predict loyalty, there have been some researchers (e.g., Cronin and Taylor, 1992; Teas, 1993), who questioned the gap model, suggesting that measuring perceptions alone might be a better indicator of service quality, than measuring the differences between expectations and perceptions (Robledo, 2001; Zeithaml et al., 1996). From a methodological point of view, it is not always easy to adopt the gap approach, since in a real life setting it requires to collect data twice (before and after using the service) from the same customers, and compare their answers. In the same vein, a study conducted by Lee et al. (2000) to test whether SERVPERF is better than SERVQUAL in measuring the overall service quality in an entertainment park stated that performance only (SERVPERF) explains more variance in the overall service quality than does the difference between expectation and performance (SERVQUAL). Additionally, a study conducted by Jain and Gupta (2004) supported the same notion and made a comparative assessment of the SERVQUAL and the SERVPERF 
scales in the Indian context, in terms of their validity, ability to explain variance in the overall service quality, power to distinguish among service objects/firms, parsimony in data collection, and, more importantly, their diagnostic ability to provide insights for managerial interventions in case of quality shortfalls. While the SERVPERF scale is a more convergent and discriminant valid explanation of the service construct, it possesses greater power to explain variations in the overall service quality scores, and can also be regarded as a parsimonious data collection instrument. This study found that when one is interested simply in assessing the overall service quality of a firm or making quality comparisons across service industries, one can employ the SERVPERF scale because of its psychometric soundness and instrument parsimoniousness. In the same context, Cronin and Taylor (1994) defended that the SERVPERF can provide practical values to managers. They argued that the performance-based measure of service quality could offer a longitudinal index of the service quality perceptions, relative to time and customer subgroups. Their final thoughts did not commit them to remain supportive to the SERVQUAL, yet remained confident of their SERVPERF.

Previous studies have shown that a perception study based on tourist experiences has been widely utilized to measure service or product quality. The SERVPERF model introduced by Cronin and Taylor (1992) is regarded as one of the most popular models. This model improved the five service quality constructs of SERVQUAL: tangibles, reliability, responsiveness, assurance and empathy. Different from SERVQUAL, the SERVPERF model collects opinions on service quality based on the perceptions of tourists after experiencing or using the services or products. A perception study is based on the argument that tourist satisfaction is a consequence of service quality (Kumra, 2008). Tourist satisfaction can thus be explained by the positive perception a visitor gains as a result of his/her experience (lee, 2009) after using a service or product (lee, 2009; khan, 2003). Therefore, the SERVPERF model is proposed to consider performance attributes of Parasuraman's SERVQUAL model (Bouranta et al., 2009). According to Ko (2005), in cases where technical measurements of the services or products received by tourists are difficult to obtain, tourist perception can serve as a valuable tool to assess the quality of services or products. In relation, perception study (SERVPERF) is argued to be relatively easy to conduct. As opposed to a service gap study (SERVQUAL) that involves data collection before tourists leave for their trips (tourist expectation) and after they complete their trips (tourist perception) (Yusof et al., 2010; khan, 2003). Unlike the SERVQUAL model, which faced much criticism because of its use of expectations in measuring service quality $(\mathrm{v}, 1993)$, the SERVPERF model is argued to be capable of explaining higher variances (Cronin and Taylor, 1992) and yielding better results (Asubonteng et al.,1996).

\section{Table (1): Examples of application of the SEVPERF scale in leisure, tourism and hospitality}

\begin{tabular}{|c|c|c|}
\hline $\begin{array}{l}\text { Lee, Haksik, Yongki Lee, and } \\
\text { Yoo (2000) }\end{array}$ & entertainment park & $\begin{array}{l}\text { Modified SERVQUAL scale } \\
\text { and SERVPERF(15 items) }\end{array}$ \\
\hline Soliman and Alzaid (2002) & Rihayds hotels & $\begin{array}{l}\text { SERVQUAL scale and } \\
\text { SERVPERF }\end{array}$ \\
\hline $\begin{array}{l}\text { Johns, Avci and. Karatepe } \\
\text { (2004) }\end{array}$ & Travel Agents Northern Cyprus & $\begin{array}{lll}\text { SERVQUAL } & \text { scale } & \text { and } \\
\text { SERVPERF } & & \end{array}$ \\
\hline $\begin{array}{l}\text { Hudson, Paul Hudson and } \\
\text { Miller (2004) }\end{array}$ & Tour Operating Sector & $\begin{array}{lll}\text { SERVQUAL } & \text { scale } & \text { and } \\
\text { SERVPERF } & & \end{array}$ \\
\hline Qin and Prybutok,2008 & Fast-Food Restaurants & $\begin{array}{l}\text { Modified SERVPERF scale ( } 21 \\
\text { items) }\end{array}$ \\
\hline $\begin{array}{l}\text { Mey and Badaruddin } \\
\text { Mohamed (2010) }\end{array}$ & MUSEUM IN MALAYSIA & $\begin{array}{lll}\begin{array}{l}\text { Modified } \\
\text { (35items) }\end{array} & \text { SERVPERF } & \text { scale } \\
\end{array}$ \\
\hline $\begin{array}{l}\text { Krishnankutty and Kalita } \\
\text {,2011 }\end{array}$ & Aviation Sector in Agartala & SERVPERF model \\
\hline Aldehayyat (2011) & Jordanian Hotels & SERVPERF model \\
\hline Abdullah et al. (2012) & 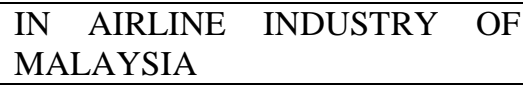 & SERVPERF model \\
\hline Ahmad, and Qadir (2013) & Kashmir tourism destination & SERVPERF model \\
\hline
\end{tabular}

Source: based on literature review

In light of the above discussion and due to the criticism faced the SERVQUAL, the current study employed SERVPERF scale to measure service quality. This is in order to test its relationships with customer satisfaction and behavioural intention.

\section{Service quality and customer satisfaction}

One of the biggest contemporary challenges of management in service industries is providing and maintaining customer satisfaction. Service quality and customer satisfaction have increasingly been identified as key factors in the battle for 
competitive differentiation and customer retention. The increased competition between leisure service businesses has forced managers to place greater importance on understanding and satisfying their customers' requirements. Like other service industries, hospitality research is focusing on the relationship between customer satisfaction and repeated sales. Customer satisfaction is one of the most important sources of competitive advantage and its accurate measurement is thus essential for the positioning or repositioning of the service mix to meet customers' needs (Ispas et al., 2010).

According to Spreng and Mackoy (1996), there is no clear definition of satisfaction, although most definitions would involve "an evaluative, affective or emotional response". This has resulted on a number of approaches used to define customer satisfaction. Zeithaml and Bitner (2000), for example, described it as "the customer's evaluation of product or service in terms of whether that product or service has met their needs and expectations". Considering the travel industry, where the product offering addresses hedonistic (leisure) needs, satisfaction is defined by Oliver (1997, 1999) "as pleasurable fulfilment." Therefore, the overall experience of the tourist is evaluated based on fulfilment of his/her needs, wants, desires and hopes. Consequently, "satisfaction is the tourist's sense that consumption provides outcomes against a standard of pleasure versus displeasure" (Kobylanski, 2012). The discrepancy between perceived service quality and satisfaction is important because managers need to know whether their objective is to provide the maximum level of perceived service quality or to have satisfied customers. The standard of comparison in forming satisfaction is predictive expectations, or what the consumer believes will happen. Perceived service quality is the result of a comparison of performance and what the consumer feels a firm should provide (Shonk, 2006). One of the widespread determinants of overall customer satisfaction is perceived quality (Fornell et al., 1996). In contrast, many researchers agreed that perceived service quality and customer satisfaction need to be treated as distinctive constructs. According to this view, perceived service quality is evaluated by the actual performance of the service in terms of particular service attributes in a specific context, whereas customer satisfaction is assessed by the customers' overall experience of the service (Oliver, 1997). Customer satisfaction, thus, depends on a variety of factors, including perceived service quality, customers' mood, emotions, social interactions, and other experience-specific subjective factors (Oliver and Rust, 1994).

Generally, satisfying consumers in tourism is important for three main reasons (Swarbrooke and Horner, 1999): First, it leads to the positive word-of-mouth which in turn brings in new customers. Second, creating repeat customers by satisfying them with their first use of the product brings a steady source of income with no need for extra marketing expenditure. Third, dealing with complaints is expensive, time-consuming and would harm reputation of organizations. Furthermore, it can bring direct costs through compensation payments (Abdalla, 2008). In the tourism industry, quality of consistent delivery and visitor services according to particular expected standards has become one of the major challenges for the destination management as it is a crucial condition for destinations' success in the competitive tourism market. On another hand, service quality has become a great predictor of outcomes, such as customer satisfaction (Atilganet et al., 2003). In destination marketing, tourist satisfaction is considered to be very important, as it is influential in the choice of destinations, the consumption of products and services, and the tourists' decision to return (Kozak and Rimmington, 2002). Bowen and Clarke (2002) indicated that measurement between service qualities with tourist satisfactions allows destination management to fully understand how to provide the best possible service quality to satisfied tourists.

Although, service quality and customer satisfaction are different concepts, they are closely related. According to some authors, satisfaction represents an antecedent of service quality (Carman, 1990; Bolton and Drew, 1991). In this sense, satisfactory experience may affect customer attitude and the assessment of perceived service quality. Thus, satisfaction with a specific transaction may result in a positive global assessment of service quality. Contrary, some researchers claimed that service quality is an antecedent of customer satisfaction (Oliver, 1997; Oh, 1999; Zeithaml and Bitner, 2000). This group of authors suggested that service quality is a cognitive evaluation which may lead to satisfaction. Hence, customer satisfaction is the result of service quality (Holjevac et al., 2009). The current study adopted the latest point of view in which service quality as a process will cause customer satisfaction as an output. A second debate within the literature relates to the relationship between service quality and customer satisfaction. Satisfied customers tend to be loyal to the company and more likely to return (Greenwell et al., 2002). In the tourism and recreation field, distinctions have been made between quality of opportunity or performance, and satisfaction or/and quality of experience. The quality of performance, which may also be termed as quality of opportunity, refers to the attributes of a service which are primarily controlled by a supplier. It is the output of a tourism provider. Evaluations of the quality of performance are based on tourists' perceptions of the performance of the provider. In contrast, satisfaction refers to an emotional state of mind after exposure to the opportunity. It recognizes that satisfaction may be influenced by the social-psychological state a tourist brings to a site (mood, disposition, needs) and by extraneous events (for example climate, social group interactions) that are beyond the provider's control, as well as by the program or site attributes that suppliers can control. Thus, performance quality is conceptualized as a measure of a provider's output, whereas the level of satisfaction is concerned with measuring a tourist's outcome. All else equal, higher quality performance in facility provision, programming, and service are likely in facility provision, programming, and service is likely to result in a higher level of visitor satisfaction. However, extraneous variables associated with factors outside the control of the provider make it likely to be a less than perfect correlation between the two 
measures. Tian-Cole and Crompton (2003) asserted that there is an agreement that service quality and tourist satisfaction are unique and different constructs. They strengthen their position by arguing that service quality contributes to the overall satisfaction. It can, therefore, be viewed as one of the factors that determine tourist satisfaction. Other factors are the experience, desired outcomes, perceptions, needs, and desires.

With the argument given above, it is clear that there is a need to clarify the relationship between service quality and tourist satisfaction in terms of differences and similarities. This is in order to evaluate variables that contribute to the satisfaction of tourist. In this regard, Tian-Cole and Crompton (2003) stated that "service quality relates to the quality of opportunities or performance of management while satisfaction relates to the psychological outcome resulting from the experience, which is out of direct control of management". It can then be concluded that the relationship between quality and satisfaction is complex. Yet, some authors have described it as Siamese twins (Danaher and Mattsson, 1994), However, other researchers percieved service quality and customer satisfaction as separate concepts that have a causal ordering (e.g. Holjevac et al., 2009). Several studies have investigated the relationship of service quality with customer behavioural patterns (Kandampully and Suhartanto, 2000; Dimitriades, 2006; Olorunniwo et al., 2006; Chi and Qu, 2008; Faullant et al., 2008). According to the findings of these studies, customer satisfaction increases customer loyalty, influences repurchase intentions and leads to positive word-of-mouth.

\section{Customer satisfaction and behavioural intentions}

Many researchers (e.g. Ryu and Han, 2010) asserted that there is a significant relationship between customer satisfaction and behavioural intention. Saha and Theingi (2009) stated that behavioural intention is a customer's subjective chance of performing a certain behaviour connected to behavioural aspects. Thus, positive behaviour can support organization's profitability and increase market share. A behavioural intention differs between more and less satisfied customers (Soderlund, 1998). Positive behaviour reduces the cost of marketing, and it may increase revenue if new customers are attracted (Riechheld and Sesser, 1990). It seems, hence, reasonable that satisfaction has a positive influence on post purchase behaviour (Cronin and Taylor, 1992; Fornell, 1992; Keaveney, 1995; Oliver, 1980; Jones and Suh, 2000). AppiahAdu et al. (2000) stated that the greater the satisfaction the more likely that tourists return to the destination and recommend it (Abdalla, 2007). However, other empirical studies have not confirmed such a direct relationship (Sivadas and BakerPrewitt, 2000). In attempting to explain these conflicting findings, Rust and Zahorik (1993) suggested that a satisfied customer might change to an alternative destination with a view to increasing the present satisfaction level whereas a dissatisfied customer might remain with the existing destination because no better alternatives are available.

\section{Service quality, customer satisfaction and behavioural intention}

The causal relationship between service quality, customer satisfaction, and behavioural intention is of increasingly academic and management interests (Ladhari, 2009; Ryu and Han, 2010). There is a strong evidence in academic research that links service quality with behavioural intentions, without controlling customer satisfaction. In contrast, Ruy and Han (2010), Zeithmal et al. (1996) and Pandey and Joshi (2010) indicated that customer satisfaction mediates between service quality and behavioural intention. The primary motivation among tourism providers for investing effort in evaluating and improving their quality of performance and seeking to enhance the level of satisfaction is that such improvements will result in increased visitation and/or revenues. Similarly, in the tourism marketing field, few studies investigated the relationships between service quality with customer satisfaction and behavioural intention in one model (Zeithaml, Berry and Parasuraman 1996), at which perceptions of high quality are found to be positively affected intended behaviour. Surprisingly, Gotleib et al. (1994) added that effects of perceived quality and satisfaction on behavioural intentions have seldom been examined when both variables are included in a model. These results inspire the need for further research on the relationship between service quality with customer satisfaction and behavioural intention in one model.

\section{Research framework and hypotheses}

The aim of this section is to propose a conceptual framework illustrating the relationship between perceived service quality with customer satisfaction and behavioural intention. A conceptual framework is a structure of concepts which are pulled together as a map for the study (Liehr and Smith, 2009). A conceptual framework is a fundamental part of a quantitative research study as it explains the research questions or hypotheses (Collis and Hussey, 2003; Punch, 2005). The conceptual framework, basically, represents a movement from confusion to certainty (Dwivedi, 2008) and provides clarity, focus and simplicity to the research task (Punch, 2005). Moreover, it clears away all the issues and materials that are not germane to the research topic and question (Dwivedi, 2008), helps to make explicitly what we already know and think about the research topic (Punch, 2005) and finally it provides structure and coherence to the researcher's dissertation (Dwivedi, 2008).

An extensive critical review of the previous studies that investigated the perceived service quality with customer satisfaction and behavioural intention has been conducted. Reviewing literature has assisted in proposing a conceptual framework and hypotheses to serve the purpose of the current study. This study investigates the causal relationship between 
perceived service quality - as an independent variable- with customer satisfaction and behavioural intention - as a dependent variable- as shown in figure 1. Based on previous several studies such as those conducted by Athanassopoulos (2000); Baker and Crompton (2000); Chen, (2008); Chen and Tsai (2007); Cronin et al. (2000); Petrick and Backman (2002); Zeithaml et al. (1996), perceived service quality -as a multidimensional construct containing six dimension- is supposed to has positive relationship with customer satisfaction and behavioural intention.

In particular, tangibility dimension describes tangibles as "physical facilities, equipment, and staff appearance (Parasuraman et al., 1988, p.23), is supposed to have positive relationship with customer satisfaction and behavioural intention:

Hypothesis 1: Tangibility has a positive effect on customer satisfaction.

Hypothesis 2: Tangibility has a positive effect on behavioural intention.

Reliability dimension -of perceived service quality- describes reliability as "ability to perform the promised service dependably and accurately" (Parasuraman et al., 1988, p.23). On other words, the ability involves performing the promised service dependably and accurately. Doing it right the first time, this is one of the most important service components for customers. Reliability also extends to provide services when promised and maintain error-free records. Reliability dimension is supposed to have positive relationship with customer satisfaction and behavioural intention:

Hypothesis 3: Reliability has a positive effect on customer satisfaction.

Hypothesis 4: Reliability has a positive effect on behavioural intention.

Responsiveness dimension -of perceived service quality- describes responsiveness as "willingness to help customers and provide prompt service" (Parasuraman et al., 1988, p.23). In other words, employees are willing to help customers and provide prompt service to customers such as quick service, professionalism in handling and recovering from mistakes. Responsiveness dimension then is supposed to have positive relationship with customer satisfaction and behavioural intention:

Hypothesis 5: Responsiveness has a positive effect on customer satisfaction.

Hypothesis 6: Responsiveness has a positive effect on behavioural intention.

Assurance dimension -of perceived service quality- describes assurance as "knowledge and courtesy of employees and their ability to inspire trust and confidence" (Parasuraman et al., 1988, p.23). Here by, assurance refers to the knowledge and courtesy of employees and their ability to convey trust and confidence including competence, courtesy, credibility, and security. Based on this, assurance dimension is supposed to have positive relationship with customer satisfaction and behavioural intention:

Hypothesis 7: Assurance has a positive effect on customer satisfaction.

Hypothesis 8: Assurance has a positive effect on behavioural intention.

Empathy -of perceived service quality- describes empathy as "caring, individual attention the firm provides its customers" (Parasuraman et al., 1988, p.23). In other words, empathy refers to the provision of caring and individualized attention to customers including access, communication and understanding the customers. Based on this, empathy dimension is supposed to have positive relationship with customer satisfaction and behavioural intention:

Hypothesis 9: Empathy has a positive effect on customer satisfaction.

Hypothesis 10: Empathy has a positive effect on behavioural intention.

Finally customer satisfaction regarding accommodation, food and beverages, transportation, and attraction is supposed to have positive relationship with behavioural intention to return to Egypt or recommends Egypt to others:

Hypothesis 11: customer satisfaction has a positive effect on behavioural intention 




Figure (1): Research framework

\section{Methodology}

The current study adopts the positivist philosophy because: (1) this study aims to evaluate tourism service quality with regard to customer satisfaction and behavioural intention. The relationship has been previously investigated in the literature; however, the findings of prior empirical studies are ambiguous and even contradictory. This motivates to get more insights and to further test such relationships. This is in order to gain a better understanding of the subject. Therfore, the positivist philosophy is more suitable to use in this situation since, this philosophy is used when theory is available, variables can be easily identified and the studies are "highly structured" (Creswell, 1994); (2) According to the research objectives, this research attempts to study the causal relationship between tourism service quality with customer satisfaction and behavioural intention. This can be accomplished by using the positivist paradigm. Collis and Hussey (2003, 53) contend that "according to positivists paradigm, explanation consists of establishing causal relationships between the variables by establishing causal laws and linking them to a deduction or integrated theory.

Additionally, the current study adopted the deductive approach for the following reasons: (1) the deductive approach is related more to the positivist philosophy (Saunders et al., 2007) which has been preferred as the current research philosophy. (2) the research hypotheses are derived from the proposed conceptual framework which explained the relationship between tourism service quality to customer satisfaction and behavioural intention. Additionally, quantitative data are collected to examine research hypotheses and test the identified outcomes. Accordingly, these steps in fact fit only the deductive approach (Creswell, 2003; Saunders et al. 2007).

The researcher used the two methods of data collection. Secondary methods were employed through searching in several database sources to complete the current study literature. Regarding primary methods, several methods can be employed, depending on the research questions and objectives (Saunders et al., 2003). For the current study, the data were collected through using a self-administered questionnaire. A questionnaire is "a set of carefully designed questions given in exactly the same form to a group of people in order to collect data about some topic(s) in which the researcher is interested" (Sapsford and Jupp, 2006). This method of data collection is used because it fits the current study philosophy (positivism), and approach (deductive). It is also can enable the researcher to collect a large amount of data from a sizeable population in a highly economic way (Saunders et al., 2003; Sapsford and Jupp, 2006).

The current study target population is the entire British tourist that visited Egypt (around 1.034.000 for 2011 based on the Egyptian Ministry of Tourism (2011)). However, the findings of the current study can be generalized to a wider population (all European tourists) because they all supposed to have similar cultures and traditions. The term sampling refers to "the methods that researchers use to select the groups, objects, or phenomena that they actually observe' (Thyer, 2001:41).

\section{Data analysis techniques}

The quantitative data were analyzed through three continuous stages of analysis: (1) preliminary analysis (screening data prior to analysis), (2) descriptive analysis, and (3) multivariate analysis. Generally, preliminary analysis aims at establishing/testing necessary conditions prior to multivariate analysis. It is investigated some issues such as addressing missing data, dealing with outliers, test of normality, multicollinearity, and linearity. Preliminary analysis also included sample size and sample bias to measure the differences between groups or variables (e.g. T-test). The next stage was 
concerned with some descriptive analysis, which included some dispersion measures; and some information regarding the distribution of scores. Furthermore, multivariate analyses using structural equation modelling was used to investigate the direct and indirect effects between the variables of the study's proposed model.

\section{Results and discussions}

\section{Structural equation modelling}

To assess the structural model goodness of model fit (GOF), several measures were employed such as measures of absolute fit: $\chi 2 / d f$, standardized root mean square residual (SRMR), and Root Mean Square Error of Approximation (RMSEA); measures of incremental fit: Comparative Fit Index (CFI), Normed Fit Index (NFI), and Tucker Lewis Index TLI; and measure of parsimony fit : Parsimony Comparative Fit Index (PCFI) and Parsimony Normed Fit Index (PNFI) (Hair et al., 2006; Byrne, 2006). Table (2) and figure (1) presents the information on selected fit indices from the output used in the evaluation of the structural model. Table (1) and figure (1) confirm that the model fits the data well.

Table (2): Summary of model fit indices for the proposed research model

\begin{tabular}{|c|c|c|c|c|c|c|c|c|}
\hline \multirow{3}{*}{$\begin{array}{c}\text { Research } \\
\text { model }\end{array}$} & \multicolumn{8}{|c|}{ Obtained fit indices } \\
\hline & \multicolumn{3}{|c|}{ AFM } & \multicolumn{3}{|c|}{ IFM } & \multicolumn{2}{|c|}{ PFM } \\
\hline & CMIN/df & RMSEA & SRMR & CFI & NFI & TLI & PNFI & PCFI \\
\hline & 1.53 & 0.029 & 0.028 & 0.943 & 0.925 & 0.912 & 0.808 & 0.812 \\
\hline \multicolumn{9}{|c|}{ Suggested fit indices } \\
\hline & $\leq 3$ & $\leq 0.08$ & $<0.05$ & $\geq 0.90$ & $\geq 0.90$ & $\geq 0.90$ & $>0.5$ & $>0.5$ \\
\hline
\end{tabular}

Suggestion for indices were adapted from literature (Byrne, 2006; Hair et al., 2006; Raykov and Marcoulides, 2006; Tabachnic and Fidell, 2007)

\section{Hypothesis testing and discussion}

After obtaining a satisfactory model fit, research hypotheses were tested. Each path in the structural model between the latent variables represents a specific hypothesis (see Figure1). According to the proposed research model, there are eleven hypotheses representing the proposed relationships among research variables. Structural equation model using AMOS v17 was employed to test the null hypothesis (estimate equals zero) of these relationships (between the latent factors) as shown in Figure1. Those relationships investigate the direct and indirect relationships between service quality dimensions with customer satisfaction and behavioural intention.

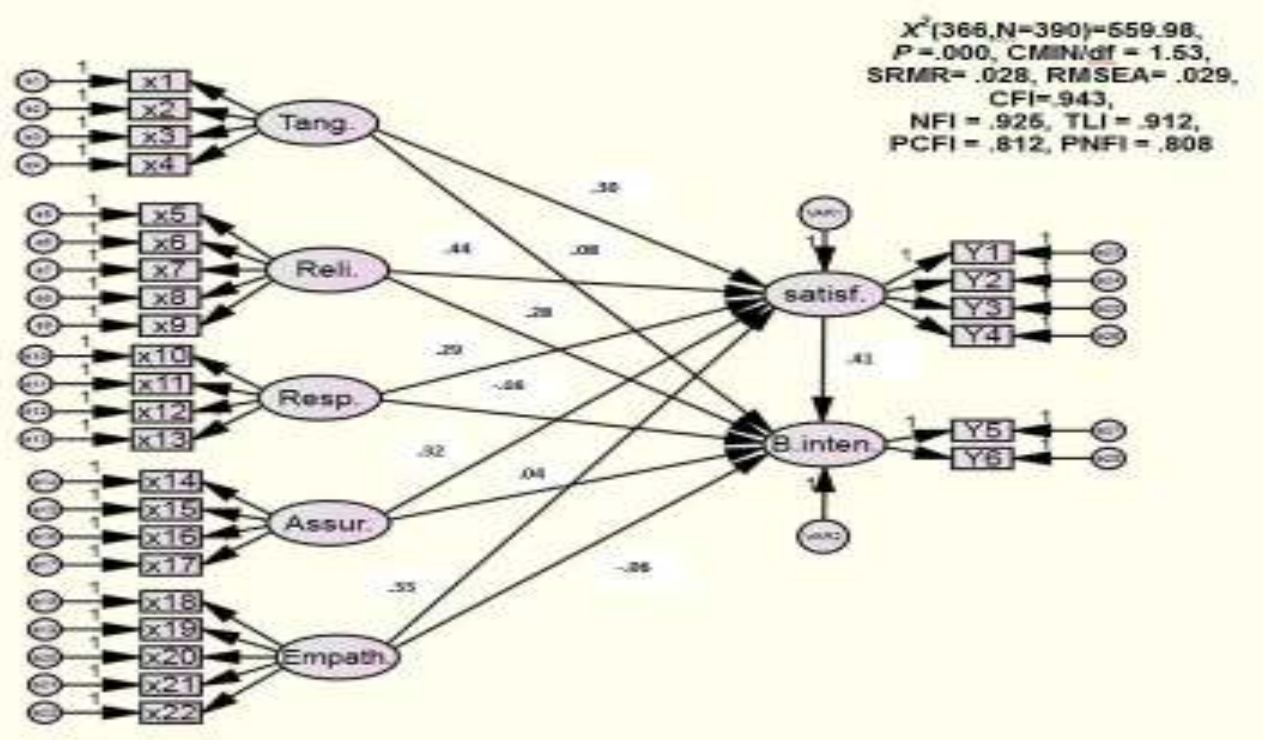

Figure (2): Structural and measurement model 
Table 3 presents selected output from AMOS v17 showing the hypotheses, standardized (estimates) regression weights, standard error, critical ratio, the p-value, null hypothesis estimation, and interpretation. According to the table, the results of the SEM show positive standardized parameter estimates and significant p-value for the impact of tangibility on customer satisfaction (path coefficient $=0.30, \mathrm{P}<.001$ ). This result might confirm that tangibility (physical facilities, equipment, and staff appearance) can improve customer satisfaction. These results are consistent with those reported by Harr (2008), and Nadiri (2008). While the positive significant direct effect of tangibility on behavioural intention is not supported (path coefficient $=0.080$ ) at probability level $(\mathrm{P})<.05$. This result indicates that tangibility (physical facilities, equipment, and staff appearance) cannot directly convince tourists to visit Egypt again or recommend other to visit Egypt (behavioural intention) but can only effect behavioural intention indirectly through satisfying customer first.

The findings of SEM, also, show positive standardized parameter estimates and significant p-value for the impact of reliability on customer satisfaction (path coefficient $=0.44, \mathrm{P}<.001$ ); and behavioural intention (path coefficient $=0.28, \mathrm{P}$ $<.001$ ). These results confirms that the ability to perform the promised service dependably and accurately (reliability dimension of perceived service quality) can not only satisfy customers (tourists) (overall satisfaction regarding accommodation, food beverages, attraction, and price) but also can impact directly the behaviour intent to revisit Egypt or recommend visiting Egypt to others. These results are consistent with those reported by Juwaheer and Ross (2003), Sriyam (2010), Pandey and Joshi,(2010); and Agbor (2011). 
Table (3): Hypothesised relationships, Standardised Regression Weights, P-values, and null hypotheses supported/rejected

\begin{tabular}{|c|c|c|c|c|c|c|c|}
\hline & Hypothesised Relationships & $\begin{array}{l}\text { Standardised } \\
\text { estimate }\end{array}$ & S.E. & $\begin{array}{c}\text { C.R. } \\
(T \text {-value })\end{array}$ & $P$ & $\begin{array}{c}\text { Null hypothesis } \\
\text { (estimate equals } \\
\text { zero) }\end{array}$ & interpretation \\
\hline H1 & Satis. $\quad<---\quad$ Tang. & .307 & .030 & 5.256 & $* * *$ & Rejected & $\begin{array}{l}\text { Tang. has a positive direct effect on customer satisfaction } \\
\qquad(\text { effect size }=.307)\end{array}$ \\
\hline $\mathbf{H 2}$ & B.Inten. <---- $\quad$ Tang. & .080 & .078 & 1.196 & .232 & Fail to Reject & $\begin{array}{l}\text { The positive direct effect of Tang. on behavioural intention is } \\
\text { not supported at probability level }(P)<.05 \text { (e.g. t-value }<.196)\end{array}$ \\
\hline $\mathbf{H 3}$ & Satis. $\quad<----$ Reli. & .441 & .039 & 6.088 & $* * *$ & Rejected & $\begin{array}{l}\text { Reli. has a positive direct effect on customer satisfaction (effect } \\
\qquad \text { size }=.441 \text { ) }\end{array}$ \\
\hline H4 & B.Inten. <---- Reli. & .285 & .106 & 3.291 & $* * *$ & Rejected & $\begin{array}{l}\text { Reli. has a positive direct effect on behavioural intention (effect } \\
\qquad \text { size }=.285 \text { ) }\end{array}$ \\
\hline H5 & Satis. $<---\quad$ Resp. & .292 & .029 & 4.841 & $* * *$ & Rejected & $\begin{array}{l}\text { Resp. has a positive direct effect on customer satisfaction } \\
(\text { effect size }=.292)\end{array}$ \\
\hline H6 & B.Inten. <--- Resp. & -.085 & .076 & -1.233 & .217 & Fail to Reject & $\begin{array}{l}\text { The positive direct effect of Resp. on behavioural intention is } \\
\text { not supported at probability level }(P)<.05 \text { (e.g. t-value }<.196)\end{array}$ \\
\hline $\mathbf{H} 7$ & Satis. <--- Assur. & .325 & .028 & 5.360 & $* * *$ & Rejected & $\begin{array}{l}\text { Assur. has a positive direct effect on customer satisfaction } \\
\qquad(\text { effect size }=\mathbf{. 3 2 5})\end{array}$ \\
\hline H8 & B.Inten. <---- Assur. & .043 & .075 & .609 & .542 & Fail to Reject & $\begin{array}{l}\text { The positive direct effect of Assur. on behavioural intention is } \\
\text { not supported at probability level }(P)<.05 \text { (e.g. t-value }<.196)\end{array}$ \\
\hline H9 & Satis. <--- Empath. & .330 & .038 & 4.764 & $* * *$ & Rejected & $\begin{array}{l}\text { Empath. has a positive direct effect on customer satisfaction } \\
\text { (effect size }=.330)\end{array}$ \\
\hline H10 & B.Inten. <---- Empath. & -.061 & .098 & -.767 & .443 & Fail to Reject & $\begin{array}{c}\text { The positive direct effect of Empath. on behavioural intention } \\
\text { is not supported at probability level }(P)<.05 \text { (e.g. t-value < } \\
.196)\end{array}$ \\
\hline H11 & B.Inten. <---- Satis. & .419 & .227 & 4.179 & $* * *$ & Rejected & $\begin{array}{c}\text { Customer satisfaction. has a positive direct effect on } \\
\text { behavioural intention (effect size }=.419 \text { ) }\end{array}$ \\
\hline
\end{tabular}

Satis.: Customer Satisfaction; Reli.: Reliability; Assur. : Assurance; Resp.: Responsiveness; Empath.: Empathy; B.Inten.: Behavioural intention; S.E.:

standard error; C.R.: critical ratio 
The results of the SEM, also, provide evidence of positive standardized parameter estimates and significant p-value for the impact of responsiveness on customer satisfaction (path coefficient $=0.29, \mathrm{P}<.001$ ). These results confirm that customers (tourists) are satisfied when employees are willing to help them and provide prompt service such as quick service, professionalism in handling and recovering from mistakes (responsiveness dimension of perceived service quality). These results are consistent with those reported by Jun and Cai (2001); Diaz and Ruiz (2002); Joseph et al., (2005); Glaveli et al., (2006); Sriyam (2010); and Kheng, and et al., (2010). While the positive significant direct effect of responsiveness on behavioural intention is not supported (path coefficient $=-0.085)$ at probability level $(\mathrm{P})$ $<.05$. These results confirm that responsiveness dimension of service quality cannot directly convince tourists to visit Egypt again or recommend other to visit Egypt (behavioural intention) but can only effect behavioural intention indirectly through customer satisfaction.

The path coefficient between assurance (dimension of perceived service quality) and customer satisfaction is 0.34 with a high significance $\mathrm{P}$-value $(\mathrm{P}<0.001)$. This highly significant $(\mathrm{P}<0.001)$ path coefficient provide an evidence to reject the null hypothesis (no relationship exists) and indicates that assurance has a positive direct effect on customer satisfaction. these results provide an evidence that the knowledge and courtesy of employees and their ability to convey trust and confidence including competence, courtesy, credibility, and security, can directly lead to customer satisfaction, These results are consistent with those reported by Ndubisi (2006); Kheng, and et al., (2010); and Canny (2013). While the SEM results show that assurance cannot directly convince tourists to visit Egypt again or recommend other to visit Egypt (behavioural intention) (path coefficient $=0.043, \mathrm{P}=0.54$ ) but can only effect behavioural intention indirectly through customer satisfaction.

Additionally, SEM results show that the path coefficient between empathy (dimension of perceived service quality) and customer satisfaction is 0.33 with a high significance $\mathrm{P}$-value $(\mathrm{P}<0.001)$. This highly significant $(\mathrm{P}<0.001)$ path coefficient provide an evidence to reject the null hypothesis (no relationship exists) and indicates that empathy has a positive direct effect on customer satisfaction. These results provide an evidence that the provision of caring and individualized attention to customers including access, communication and understanding the customers, can directly lead to customer satisfaction, These results are consistent with those reported by Nadiri et al. (2008); and Suki (2014). While the SEM results show that empathy cannot directly convince tourists to visit Egypt again or recommend other to visit Egypt (behavioural intention) (path coefficient $=-0.061, \mathrm{P}=0.54$ ) but can only effect behavioural intention indirectly through customer satisfaction. SEM results show that the path coefficient between customer satisfaction and behavioural intention is 0.419 with a high significance $\mathrm{P}$-value $(\mathrm{P}<0.001)$. This highly significant $(\mathrm{P}<0.001)$ path coefficient provide an evidence to reject the null hypothesis (no relationship exists) and indicates that customer satisfaction have a positive significant direct impact on behavioural intention. These results provide an evidence that when tourists are satisfied with the accommodation, food beverages, attraction, and price, they are likely to repeat visit and recommend visiting Egypt to others (behavioural intention). These results are consistent with those reported by Cronin et al., (2000); and Olorunniwo et al., (2006).

Finally, the assessment of the predictive power of the SEM results revealed that R2 for the endogenous variables are as follows: customer satisfaction (0.60), and behavioural intention (0.38). The results of the SEM predictive power indicate that the five perceived dimension of service quality (tangibility, reliability, responsiveness, assurance and empathy) can explain $60 \%$ of the variance in customer satisfaction and $38 \%$ of the variance in behavioural intention. These R2 values indicate a good predictive power, taking into consideration the substantial unexplained variance in customer satisfaction and behavioural intention, which would probably be explained by other factors including destination image, perceived value, management, safety stability of political and economic factors.

\section{Conclusion}

This study sought to investigate the impact of service quality on customer satisfaction and behavioural intention. Despite the important theoretical role of service quality in improving customer satisfaction and creating behavioural intention, fewer empirical studies have been investigating these three constructs in one model within the context of the service industry. In particular there is an absence in the tourism industry. Among those studies that investigate the impact of service quality on customer satisfaction and creating behavioural intention, there is a lack of clarity concerning the dimensional structure of service quality, which service quality can improve customer satisfaction and create behavioural intention, and whether the relationship between service quality and behavioural intention is direct or indirect through customer satisfaction. This lack of clarity might be due to differences in the dimensions that were used to measure service quality, and/or difference in the employed data analysis methods. The current study started by reviewing the literature to highlight the different definitions of service quality. Also, an extensive review of the literature was done regarding the dimensions and measurements of the service quality construct including the SERVQUAL model and the criticisms of the SERVQUAL questionnaire because it consists of 44 questions to measure customer expectations and perceptions. This may result in respondent fatigue; additionally the method of asking respondents was questionable. Specifically, a problem might occur from some respondents who might be unable to establish the expectation due to a new experience or no communication with other sources. The extension of arguments over the SERVQUAL provided more insights into the evaluation of service quality (Narangajavana, 2007). 
Moreover, in SERVQUAL, respondents must rate their expectations and perceptions of a particular service on the same scale for each of the 22 items. Respondents are often interviewed only once and questioned to rate both their expectations and perceptions on one occasion. If respondents are using these retrospective expectations in their postpurchase evaluations, the initially measured expectations can be disputable by biased experience of the respondents (Baron and Harris, 2003). Because of these several authors suggested and preferred the use of only perception of service performance to measure service quality (Narangajavana, 2007; Zhang, 2009). For more consistent results, several authors recommended using service performance "SERVPERF" (a modified SERVQUAL instrument) to measure service quality. The five dimensions of SERVQUAL scale (Parasuraman et.al., 1988) include the physical facilities, equipment and the appearance of the staff (Tangibles); the dependability and accuracy of the service provider (Reliability); the ability to know and willingness to cater to customer needs (Responsiveness); the ability of staff to instill confidence and trust in the company (Assurance); and finally, the ability of the staff in providing a caring service to customers (Empathy). Instead of measuring both customer expectations and perceptions as in the SERVQUAL, the SERVPERF was operationalized by only one part of the perceived performance. Based on the above, the SERVPERF scale was used in the current study to operationalize (measure) service quality. A conceptual framework was then developed, based on an extensive review of the previous studies, to illustrate the interrelations between the five dimensions of service quality and their impact on customer satisfaction and behavioural intention. The reader can understand the theorized relationships between these three variables. This conceptual framework guided the research, determining what variables would be measured and the statistical relationship that should be tested.

In this study, 550 questionnaires were distributed in the majority of the international Egyptian airports (Cairo airport, Alexandria airport, Borg Al Arab airport, Hurghda airport, Sharm - Al Sheikh airport, Aloksor airport, and Aswan airport) targeting the departure British tourists, around 450 questionnaires returned, of which 60 questionnaires were excluded due to an excessive number of unanswered questions, leaving a final usable total of 390, yielding a response rate of $71 \%$. The impact of service quality on customer satisfaction and behavioural intention was tested using structural equation modelling (SEM). SEM is appropriate technique that serves the purpose of the current study as it allows analyzing multiple and interrelated causal relationships among the latent constructs while taking into account the estimated measurement error. The SEM results indicated that the entire five service quality dimension: tangibility, reliability, responsiveness, assurance, and empathy directly improves customer satisfaction, while only one dimension can create behavioural intention which is reliable, but the other service quality dimensions such as tangibility, responsiveness, assurance, and empathy cannot directly create behavioural intention but can indirectly influence it through customer satisfaction.

\section{Reference}

Abdalla, M. G. (2008). Egypt's image as a tourist destination: A perspective of foreign tourists. Tourismos: An International Multidisciplinary Journal Of Tourism, 3(1), 36-65.

Abdullah, K., Jan, M. T., and Abd Manaf, N. H. (2012). A structural equation modelling approach to validate the dimensions of servperf in airline industry of malaysia. International Journal of Engineering and Management Sciences, 3(2).

Agbor, J. M. (2011). The Relationship between Customer Satisfaction and Service Quality: a study of three Service sectors in Umeå.

Akbaba, A. (2006).Measuring service quality in the hotel industry: A study in a business hotel in Turkey. International Journal of Hospitality Management,25(2), 170-192.

Aldehayyat, Jehad S and Al Khattab ,Suleiman A. (2011) Perceptions of Service Quality in Jordanian Hotels , International Journal of Business and Management Vol. 6, No. 7; July 2011

Alzaid, A.A. and Soliman, A.A. (2002). Service quality in Riyadh's Elite hotels: measurement and evaluation. J. King Saud. Univ. Admin. Sci 14(2): 83-103.

Antony, J., Antony, F. J., and Ghosh, S. (2004). Evaluating service quality in a UK hotel chain: a case study. International Journal of Contemporary Hospitality Management, 16(6), 380-384.

Appiah-Adu, K., Fyall, A., and Singh, S. (2000). Marketing culture and customer retention in the tourism industry. The Service Industries Journal, 20(2), 95-113.

Asubonteng, P. Mccleary, K.J., and Swan, J.E. (1996). SERVQUAL revisited: a critical review of service quality, The Journal of Services Marketing 10 (6), 62-81.

Athanassopoulos, A. D. (2000). Customer satisfaction cues to support market segmentation and explain switching behaviour. Journal of business research,47(3), 191-207.

Atilgan, E., Akinci, S.,and Aksoy, S. (2003).Mapping service quality in the tourism industry.Managing Service Quality, 13(5), 412-422. 
Babkus, E., Eroglu, S., and Yavas, U. (2004). Modeling consumers' choice behaviour: an application in banking. Journal of Services Marketing , 18 (6), 462-470.

Bouranta, N., Chitiris, L., and Paravantis, J. (2009). The relationship between internal and external service quality. International Journal of Contemporary Hospitality Management, 21(3), 275-293.

Bowen and Clarke (2002)

Buttle, F. (1996). SERVQUAL: review, critique, research agenda. European Journal of marketing, 30(1), 8-32.

Canny, I. U. (2013). An Empirical Investigation of Service Quality, Tourist Satisfaction and Future Behavioural intentions among Domestic Local Tourist at Borobudur Temple. International Journal of Trade, Economics and Finance, 4(2).

Carman, J. M. (1990). Consumer perceptions of service quality: an assessment of the SERVQUAL dimensions. Journal of Retailing , 66, 33-35.

Chen, C. F., and Tsai, D. (2007). How destination image and evaluative factors affect behavioural intentions?. Tourism management, 28(4), 1115-1122.

Chen, J. S., Ekinci, Y., Riley, M., Yoon, Y., and Tjelflaat, S. (2001). What do Norwegians think of US lodging services?. International Journal of Contemporary Hospitality Management, 13(6), 280-284.

Chin, A. (2002). Impact of frequent flyer programs on the demand of air travel. Journal of Air Transportation , 7 (2), 53-86.

Clemenz, C. E. (2001). Measuring perceived quality of training in the hospitality industry (Doctoral dissertation, Virginia Polytechnic Institute and State University).

Collis, J. and Hussy, R. 2003. Business Research: A Practical Guide for Undergraduate and Postgraduate Students Palgrave: Macmillan.

Creswell, J. 2003. Research Design: Qualitative, Quantitative, and Mixed Method Approaches. Sage: Thousand Oaks. CA.

Crompton, J. L., and Love, L. L. (1995). The predictive validity of alternative approaches to evaluating quality of a festival. Journal of Travel Research, 34(1), 11-24.

Cronin, J.J. and Taylor, S.A. (1994), "SERVPERF versus SERVQUAL: reconciling performance-based and perceptions-minus-expectations measurement of service quality",Journal of Marketing, Vol. 58, pp. 125-31

Cronin, J.J. Jr and Taylor, S. (1992), “Measuring service quality: a re-examination and extension”,Journal of Marketing, Vol. 56 No. 3, pp. 55-68.

Cronin, J.J. Jr and Taylor, S. (1992), "Measuring service quality: a re-examination and extension”,Journal of Marketing, Vol. 56 No. 3, pp. 55-68.

Danaher, P. J., and Mattsson, J. (1994). Customer satisfaction during the service delivery process. European journal of Marketing, 28(5), 5-16.

Diaz, A.B.C., and Ruiz, F.J.M. (2002). The consumer's reaction to delays in service. International Journal of Service Industry Management, 13(2), 118-140

Dimitriades, Z. S. (2006). Customer satisfaction, loyalty and commitment in service organizations: some evidence from Greece. Management Research News, 29(12), 782-800.

Douglas, L., and Connor, R. (2003). Attitudes to service quality-the expectation gap. Nutrition and Food Science, 33(4), 165-172.

Durvasula, S., Lysonski, S., and Mehta, S. C. (1999). Testing the SERVQUAL scale in the business-to-business sector: the case of ocean freight shipping service. Journal of Services Marketing, 13(2), 132-150.

Dwivedi, A. 2008. Lecture notes: Philosophical issues in Business and Management. Hull: University Business School.

Faullant, R., Matzler, K., and Füller, J. (2008). The impact of satisfaction and image on loyalty: the case of Alpine ski resorts. Managing Service Quality,18(2), 163-178.

Fornell, C., Johnson, M. D., Anderson, E. W., Cha, J., and Bryant, B. E. (1996). The American customer satisfaction index: Nature, purpose, and findings.Journal of marketing, 60(4).

Getty, J. M., and Getty, R. L. (2003). Lodging quality index (LQI): assessing customers' perceptions of quality delivery. International Journal of Contemporary Hospitality Management, 15(2), 94-104. 
Glaveli, N., Petridou, E., Liassides, C., and Spathis, C. (2006). Bank service quality: evidence from five Balkan countries. Managing Service Quality, 16(4), 380-391.

Gotlieb, J. B., Grewal, D., and Brown, S. W. (1994). Consumer satisfaction and perceived quality: complementary or divergent constructs?. Journal of applied psychology, 79(6), 875.

Greenwell, T. C., Fink, J. S., and Pastore, D. L. (2002). Assessing the influence of the physical sports facility on customer satisfaction within the context of the service experience. Sport Management Review, 5(2), 129-148.

Grönroos, , C. (1984). A service quality model and its marketing implication. European Journal of Marketing, 18(4), $36-44$.

Grönroos, C. (2007). Service management and marketing: customer management in service competition. John Wiley and Sons

Haghkhah, A., Nosratpour, M., Ebrahimpour, A., and Hamid, A. B. A. (2011). The impact of service quality on tourism industry. In 2nd International Conference On Business And Economic Research (2nd Icber 2011) Proceeding.

Haron, S., Ahmad, N., and Planisek, S. (1994). Bank patronage factors of Muslim and non-Muslim customers. International Journal of Bank Marketing , 12 (1), 32-40

Hersh, A,M. (2010).Evaluate the impact of Tourism Services Quality on customer's satisfaction,2010), interdisciplinary journal of contemporary research in business,2( 6).

Hoffman, K. D., and Bateson, J. E. (1997). Essentials of services marketing. Orlando, FL: Dryden Press.

Hoffman, K. D., and Bateson, J. E. (2011). Services marketing. South-Western, 2011.

Holjevac, I. A., Marković, S., and Raspor, S. (2010). ; Customer satisfaction measurement in hotel industry: content analysis study. University of Rijeka, Opatija[Links].

Hudson, S., Hudson, P., and Miller, G. A. (2004). The measurement of service quality in the tour operating sector: a methodological comparison. Journal of Travel Research, 42(3), 305-312.

Hudson, S., Hudson, P., and Miller, G. A. (2004). The measurement of service quality in the tour operating sector: a methodological comparison. Journal of Travel Research, 42(3), 305-312.

Ispas, a., constantin, c., and candrea, a. N. (2010). evaluating customer satisfaction with brasov accommodation services.Tourism and Hospitality Management.

Johns, N., Avcí, T., and Karatepe, O. M. (2004). Measuring service quality of travel agents: evidence from Northern Cyprus. The Service Industries Journal,24(3), 82-100.

Jones, M. and Suh, J. (2000), “Transaction-specific satisfaction and overall satisfaction: an empirical analysis”,Journal of Services Marketing, Vol. 14 No. 2, pp. 147-59.

Jones, M., Mothersbaugh, D., and Beatty, S. (2002). Why customers stay: measuring the underlying dimesions of services switching costs and managing their differential strategic outcomes. Journal of Business Research , 55 (6), 441-450.

Joseph, M., Sekhon, Y., Stone, G., and Tinson, J. (2005). Anexploratory study on the use of banking technology in the UK. A ranking of importance of selected technology on consumer perception of service delivery performance. International Journal of Bank Marketing, 23(5), 397-413.

Jun, M., and Cai, S. (2001). The key determinants of Internet banking service quality: a content analysis. International Journal of Bank Marketing, 19(7), 276-291.

Juwaheer, T. D., and Ross, D. L. (2003). A study of hotel guest perceptions in Mauritius. International Journal of Contemporary Hospitality Management, 15(2), 105-115

Juwaheer, T. D., and Ross, D. L. (2003). A study of hotel guest perceptions in Mauritius. International Journal of Contemporary Hospitality Management, 15(2), 105-115

Kandampully, J., and Suhartanto, D. (2000). Customer loyalty in the hotel industry: the role of customer satisfaction and image. International journal of contemporary hospitality management, 12(6), 346-351.

Keaveney, S. M. (1995). Customer switching behaviour in service industries: an exploratory study. The Journal of Marketing, 71-82.

Kettinger, W. J., Lee, C. C., and Lee, S. (1995). Global Measures of Information Service Quality: A Cross-National Study*. Decision Sciences, 26(5), 569-588.

Khan, M., (2003).ECOSERV: Ecotourists' Quality Expectations. Annals of Tourism Research,. 30(1): p. $109-124$. 
Kheng, L. L., Mahamad, O., Ramayah, T., and Mosahab, R. (2010). The Impact of Service Quality on Customer Loyalty: A Study of Banks in Penang, Malaysia.International Journal of Marketing Studies, 2(2).

Ko, T.G., Development of a tourism sustainability assessment procedure: a conceptual approach. Tourism Management, 2005. 26(3): p. 431-445.

Kobylanski, A. (2012). Attributes And Consequences Of Customer Satisfaction In Tourism Industry: The Case Of Polish Travel Agencies. Journal of Service Science (19414722), 5(1).

Kouthouris, C., and Alexandris, K. (2005). Can service quality predict customer satisfaction and behavioural intentions in the sport tourism industry? An application of the SERVQUAL model in an outdoors setting. Journal of Sport Tourism, 10(2), 101 .

Kozak, N., Karatepe, O.M. and Avci, T. (2003), "Measuring the quality of airline services: evidence from Northern Cyprus",Tourism Analysis, Vol. 8, pp. 75-87.

Krishnankutty, R.and Kalita, M. (2011) .Consumers' Perception regarding Service Quality in Aviation Sector in Agartala ,Information Management and Business Review.

Kumra, R.( 2008).Service Quality in Rural Tourism: A Prescriptive Approach. in Conference on Tourism in India-88 Challenges Ahead.: Indian Institute of Management Kozhikode.

Ladhari, R. (2009). A review of twenty years of SERVQUAL research.International Journal of Quality and Service Sciences, 1(2), 172-198.

Lee, H., Lee, Y., and Yoo, D. (2000). The determinants of perceived service quality and its relationship with satisfaction. Journal of services marketing,14(3), 217-231.

Lee, H., Lee, Y., and Yoo, D. (2000). The determinants of perceived service quality and its relationship with satisfaction. Journal of services marketing,14(3), 217-231.

Lee, M., and Cunningham, L. F. (2001). A cost/benefit approach to understanding service loyalty. Journal of services Marketing, 15(2), 113-130.

Lee, T.H.(2009)Assessing visitors' experiences at hot spring recreation areas in Taiwan. International Journal of Tourism Research, 2009. 12(2): p. 193-203.

Levesque, T., and McDougall, G. H. (1996). Determinants of customer satisfaction in retail banking. International Journal of Bank Marketing, 14(7), 12-20.

Liehr, P. and smith, M. J. 2009. Frameworks for Research. [Online] available. http://homepage.psy.utexas.edu/homepage/Class/Psy394V/Pennebaker/Reprints/Liehr\%20Class.doc [accessed November, 2009]

Mels, Gerhard, Christo Boshoff, and Deon Nel (1997), "The Dimensions of Service Quality: The Original European Per- spective Revisited," Service Industries Journal, 17 (1), 173-89.

Mey, L. P., and Mohamed, B. (2010). Service Quality, Visitor Satisfaction And Behavioural intentions: Pilot Study At A Museum In Malaysia. Journal of Global Business and Economics, 1(1), 226-240.

Moliner, M.A., Sanchez, J., Rodriguez, R.M. and Callarisa, L. (2007). Relationship quality with a travel agency: The influence of the postpurchase perceived value of a tourism package.Tourism and Hospitality Research, 7(3/4), 194-211.

Narangajavana, Y. (2007). The Relationship of the Hotel Rating System and Service Quality (Doctoral dissertation, Oklahoma State University).

Ndhlovu, J., and Senguder, T. (2002). Gender and perception of service quality in the hotel industry. Journal of American Academy of Business, 1(2), 301-307.

Ndubisi, N. O. (2006). A structural equation modeling of the antecedents of relationship quality in the Malaysia banking sector. Journal of FinancialServices Marketing, 11(2), 131-141.

Oh, H. (1999). Service quality, customer satisfaction, and customer value: A holistic perspective. International Journal of Hospitality Management, 18(1), 67-82.

Oliver, R. (1999). "Whence Consumer Loyalty?' Journal of Marketing, 63 (Special issue), 33-45.

Oliver, R. L., Rust, R. T., and Varki, S. (1997). Customer delight: foundations, findings, and managerial insight. Journal of Retailing, 73(3), 311-336.

Oliver, R.L. (1997). “Satisfaction: A behaviour perspective on the customer”, McGraw-Hill, New York. 
Olorunniwo, F., Hsu, M. K., and Udo, G. J. (2006). Service quality, customer satisfaction, and behavioural intentions in the service factory. Journal of Services Marketing, 20(1), 59-72.

Olorunniwo, F., Hsu, M.K. and Udo, G.J. (2006). Service quality, customer satisfaction and behaviour intentions in the service factory. Journal of Services Marketing, 20(1): 59-72.

Pandey, D., and Joshi, P. R. (2010). Service Quality and Customer Behavioural intentions: A Study in the Hotel Industry. California Journal of Operations Management, 8(2), 72-81.

Parasuraman, A., Zeithaml, V. A., and Berry, L. L. (1988). SERVQUAL: A multiple item scale for measuring consumer perceptions of service quality. Journal of Retailing, 64(1), 12-37.

Parasuraman, A., Zeithaml, V. and Berry, L.L. (1985).A conceptual model of service quality and its implications for future research", Journal of Marketing, Vol. 49, Autumn, pp. 41-50.

Parasuraman, A., Zeithaml, V. and Berry, L.L. (1994).Reassessment of expectations as acomparison standard in measuring service quality: implications for future research, Journal of Marketing, Vol. 58, January, pp. 111-24.

Pei, M. L., Akbar, A. K., and Yong, G. F. (2006). Measuring service quality and customer satisfaction of the Hotels in Malaysia: Malaysian, and Asian and Non-Asian Hotel Guests. Journal of Hospitality and Tourism Management , 13 (2), 144-161.

Petrick, J. F., and Backman, S. J. (2002). An examination of the construct of perceived value for the prediction of golf travelers' intentions to revisit. Journal of Travel Research, 41(1), 38-45.

Punch , K . 2005. Introduction to Social Research: Quantitative and Qualitative Approaches. London: Sage Publications.

Qin, H., and Prybutok, V. R. (2008). Determinants of customer-perceived service quality in fast-food restaurants and their relationship to customer satisfaction and behavioural intentions. Quality Management Journal, 15(2).

Radder, L. and Han, X., (2011). Measurement and Consequences of US Tourists' Perceptions of Service Quality: A South African Hunting Safari Case Study.International Business and Economics Research Journal (IBER), 10(5), 33-48.

Reichheld, F. F., and Sasser Jr, W. E. (1989). Zero defections: quality comes to services. Harvard business review, 68(5), 105-111.

Robledo, M. A. (2001). Measuring and managing service quality: integrating customer expectations. Managing service quality, 11(1), 22-31.

Rust, R. T., and Zahorik, A. J. (1993). Customer satisfaction, customer retention, and market share. Journal of retailing, 69(2), 193-215.

Ryu, K., Han, H., and Jang, S. S. (2010). Relationships among hedonic and utilitarian values, satisfaction and behavioural intentions in the fast-casual restaurant industry. International Journal of Contemporary Hospitality Management, 22(3), 416-432.

Saha, G. C. (2009). Service quality, satisfaction, and behavioural intentions: a study of low-cost airline carriers in Thailand. Managing Service Quality, 19(3), 350-372.

Santos, J. (2003). E-service quality: a model of virtual service quality dimensions. Managing service quality, 13(3), 233-246.

Sapsford, R. and Jupp, V. 2006. Data Collection and Analysis. $2^{\text {nd }}$ ed. London: Sage.

Saunders, M ., Lewis, P. and Thornhill, A. 2003. Research Methods for Business Students. 3rd ed. London: Prentice Hall.

Saunders, M., LewIS, P. and Thornhill, A. 2007. Research Methods for Business Students. $4^{\text {th }}$ ed. London: Prentice Hall.

Shonk, D. J. (2006). Perceptions of service quality, satisfaction and the intent to return among tourists attending a sporting event (Doctoral dissertation, Ohio State University).

Sivadas, E., and Baker-Prewitt, J. L. (2000). An examination of the relationship between service quality, customer satisfaction, and store loyalty. International Journal of Retail and Distribution Management, 28(2), 73-82.

Sivadas, E., and Baker-Prewitt, J. L. (2000). An examination of the relationship between service quality, customer satisfaction, and store loyalty. International Journal of Retail and Distribution Management, 28(2), 73-82.

Spreng, R.A. and Mackoy, R.D. (1996), “An empirical examination of a model of perceived servicequality and satisfaction”,Journal of Retailing, Vol. 72 No. 2, pp. 201-15. 
Suki, N. M. (2014). Passenger satisfaction with airline service quality in Malaysia: A structural equation modeling approach. Research in Transportation Business and Management.

Swarbrooke, J. and Horner, S. (1999). Butter-worth Heinemann. Oxford, pp.453.

Teas, R. K. (1993). Expectations, performance evaluation and consumer's perceptions of quality. Journal of Marketing, $57,18-34$.

Thyer, A. B. 2001. The handbook of social work research methods. Thousand Oaks, Calif: Sage Publications.

Tian-Cole, S., and Cromption, J. (2003). A conceptualization of the relationships between service quality and visitor satisfaction, and their links to destination selection. Leisure studies, 22(1), 65-80.

Tsang, N., and Qu, H. (2000). Service quality in China's hotel industry: a perspective from tourists and hotel managers. International Journal of Contemporary Hospitality Management, 12(5), 316-326.

UNWTO (2014). Tourism Highlights 2012. Madrid: World Tourism Organization.

Van Looy, B., Gemmel, P., and Dierdonck, R. (Eds.). (2003). Services Services management: An integrated approach. Pearson Education.

Yusof, N., et al., (2010), Are resort operators demanding in an environmental Protection culture? The case of Lake kenyir, Malaysia. , in Sustainable Tourism IV, C.A. Brebbia and F.D. Pineda, Editors., WIT Press UK. p. 183 194.

Zeithaml, V. A., Berry, L.L. and Parasuraman, A. (1996). The behaviour consequences of service quality. Journal of Marketing Management, 60(No. April), 31-46.

Zeithaml, Valarie A., M. J. Bitner, and Gremler. 2006. Services Marketing - Integrating Customer Focus Across the Firm. New York.

Zhang, J. (2009) An investigation into the guests' perceived service quality of the bed-and-breakfast and guest house market industry in the nelson mandela bay area, desertaion, Submitted in fulfillment of the requirements for the degree Magister Technologiae Business Administration, December 